\title{
Preculture sugarcane tissue in sucrose-supplemented culture medium to induce desiccation tolerance
}

\author{
Cristiane Gamarano Melo $^{1}$, Márcio Henrique Pereira Barbosa ${ }^{1}$, Sérgio Yoshimitsu Motoike ${ }^{1}$, Marcone Vieira Sabino ${ }^{1}$, Marília \\ Contin Ventrella ${ }^{2}$, Luiz Alexandre Peternelli ${ }^{3}$ and Márcio Antônio Rocha Oliveira ${ }^{1}$
}

Received 25 May 2010

Accepted 6 July 2011

\begin{abstract}
Cryopreservation is a promising technique for long term conservation of sugarcane's genetic resources which could be used in breeding programs. Preculture is a key step for success this technique. The purpose of this study was to evaluate the effect of sucrose concentrations and preculture period on dessication tolerance of sugarcane tissue dehydrated to 30, 20 and $10 \%$ moisture. Sugarcane shoot tips were encapsulated in sodium alginate and precultured in a liquid culture medium with $0.3,0.5$, and $0.75 \mathrm{M}$ sucrose. Preculturing in $0.3 \mathrm{M}$ sucrose was ideal to induce desiccation tolerance in tissue. This sucrose concentration reduced the percentage of electrolytic leakage. Shoot tips were sensitive to a sucrose concentration of $0.75 \mathrm{M}$, resulting in low survival rates after desiccation. Preculturing in $0.5 \mathrm{M}$ sucrose resulted in a higher survival rate after drying for 5.7 and $7.45 \mathrm{~h}$. The percentage of electrolytic leakage was high when shoot tips were desiccated after preculturing in 0.5 and $0.75 \mathrm{M}$ sucrose.
\end{abstract}

Key words: electrolytic leakage; shoot tips; tissue culture.

\section{INTRODUCTION}

To have a successful breeding program is necessary that genetic variability of the desirable characteristics of a particular species is available for its use. Thus, the germplasm banks play an important role in breeding programs. Vegetatively propagated species such as sugarcane has its germplasm preserved in the field. However, as the collections are large and occupy vast areas, the plants are exposed to the attack of pathogens, bad weather, vandalism and loss due to faults of identification (Withers and Engelmann 1998). In this context, cryopreservation is an alternative for germplasm's conservation, as it consists in a process where cells or whole tissues are preserved in liquid nitrogen at $196{ }^{\circ} \mathrm{C}$. Popov et al. (2006) suggest this process as the most reliable method for long-term storage of plant genetic resources. The main obstacle of cryopreservation is the formation of ice crystals inside the cells during freezing wich causes the death of the explant. Therefore it is used the drying whose function is to remove water from cells, in order to avoid formation of those ice crystals. However, drying causes stress in the explants, thus preculture becomes necessary to increase cell's resistance to this stress.

Sugars are considered important for tissue tolerance to desiccation and frost in many species (Lenné et al. 2007). Organisms of all kingdoms accumulate disaccharides in

\footnotetext{
${ }^{1}$ Universidade Federal de Viçosa (UFV), Departamento de Fitotecnia, Laboratório de Cultura de Tecidos, 36.570-000, Viçosa, MG, Brazil. *E-mail: barbosa@ ufv.br ${ }^{2}$ UFV, Departamento de Biologia Vegetal, Laboratório de Anatomia Vegetal

${ }^{3}$ UFV, Departamento de Tecnologia da Informação
} 
response to various kinds of stresses, e.g., temperature, oxidative and osmotic stress. Higher plants often accumulate sucrose due to cold or drought stress (Hoekstra et al. 2001a). The adaptation of plants to an unfavorable environment is correlated to the need to survive the stress (Machado Neto et al. 2004). According to Machado Neto and Durães (2006), gradual changes in environmental conditions are also capable of inducing tolerance to extreme situations in many plants.

A number of studies have focused on the ability of sugars to protect the double lipid layer and proteins against drought and frost (Oliver et al. 2002). Membranes change from the liquid to the gel phase when dried; this causes solute leakage, membrane fusion, and protein denaturation (Bogaart et al. 2007). Sugars protect membranes by forming a vitreous matrix and by interacting directly with lipids (Koster et al. 2000, Crowe et al. 2001, Cacela and Hincha 2006). This interaction helps stabilize cell membranes during drought and frost, maintaining the membrane functions by minimizing damage to the lipid double layer.

The encapsulation-dehydration technique developed by Fabre and Dereuddre (1990) is based on technology used in the development of artificial seeds. This technique consists of encapsulating explants in sodium alginate capsules that efficiently protect explants from dehydration (Verleysen et al. 2005). The encapsulated explants are generally precultured in high sucrose liquid media (0.1 $1.5 \mathrm{M}$ ) for one or two days, inducing desiccation tolerance in tissues or plant organs (Sakai 2004).

When the water content of a cell falls to say 10 or $20 \%$, all the nonaqueous components are crushed very close together (Wolfe and Bryant 1999). According to Hoekstra et al. (2001a), only sugars can structurally and functionally preserve proteins and membranes below $23 \%$ moisture content by water replacement. The purpose of this study was to study the effect of sucrose concentrations and preculture period on resistance of sugarcane tissue when dried to 30,20 and $10 \%$ moisture.

\section{MATERIAL AND METHODS}

\section{Establishment in vitro}

Shoot meristems (7-8 cm explants) were taken from sugar cane (Saccharum spp., variety RB72454) tips, washed in diluted commercial detergent in distilled water at 1:1 (1 detergent: 1 distilled water) for $10 \mathrm{~min}$, pre-disinfected in $2.5 \%$ Cercobin $700\left(\mathrm{p} \mathrm{v}^{-1}\right)$, and then $20 \mathrm{~min}$ in sodium hypochlorite (1.0-1.25\% active chloride) $\left(\mathrm{p} \mathrm{v}^{-1}\right)$. In a flow chamber, explants were disinfected with $70 \%$ alcohol $\left(\mathrm{v} \mathrm{v}^{-1}\right)$ for $1 \mathrm{~min}$, and $20 \mathrm{~min}$ in commercial $\mathrm{NaOCl}$ (2.0$2.5 \%$ active chloride) $\left(\mathrm{p} \mathrm{v}^{-1}\right)$; after each disinfection step, explants were washed three times in autoclaved distilled water. Explants were inoculated aseptically and separately in test tubes (10 per $150 \mathrm{~mm}$ ) containing $10 \mathrm{~mL}$ of a Murashige and Skoog (1962) basal medium (MS medium) with $30 \mathrm{~g} \mathrm{~L}^{-1}$ sucrose, $100 \mathrm{mg} \mathrm{L}^{-1}$ myo-inositol, $100 \mathrm{mg} \mathrm{L}^{-1}$ citric acid, $40 \mathrm{mg} \mathrm{L}^{-1}$ cystein, $15 \mathrm{mg} \mathrm{L}^{-1}$ ascorbic acid, $2.0 \mathrm{mg} \mathrm{L}^{-1}$ silver nitrate, solidified with $7.0 \mathrm{~g} \mathrm{~L}^{-1}$ agar, $1.16 \mu \mathrm{M}$ kinetin, and 2.22 $\mu \mathrm{M}$ 6-benzylaminopurine (BAP); this culture medium was named basic culture medium (BM). Explants were incubated at controlled room temperature $27 \pm 2{ }^{\circ} \mathrm{C}$, with a $16 \mathrm{~h}$ photoperiod and $\pm 52 \mu \mathrm{mol} \mathrm{m}^{-2} \mathrm{~s}^{-1}$ radiance.

At tillering, tillers were transplanted and transferred to flasks containing $30 \mathrm{~mL}$ of BM. Plants were incubated under similar conditions as described above and transplanted every 25 days until enough shoot tips with 3-4 primordial leaf pairs and the basal portion had been collected for the experiments.

\section{Encapsulation}

Shoot tips (3-4 mm) were extracted from buds (8$10 \mathrm{~cm}) 15$ days after the last transplant. After extraction, tips were transferred into BM without growth regulators for 12 hours to recover from extraction stress. Next, tips were encapsulated in liquid BM without calcium or growth regulators but with $3 \%\left(\mathrm{p} \mathrm{v}^{-1}\right)$ alginic acid sodium salt and polymerized for $10 \mathrm{~min}$ in a $100 \mathrm{mM}$ calcium nitrate solution. Each capsule (7-8 mm) contained one shoot tip.

\section{Moisture determination of capsules}

An experiment was conducted to determine the appropriate periods to attain 30, 20 and $10 \%$ moisture content. The polymerized capsules were transferred to Petri dishes and the wet weight at time zero determined on analytical scales. Petri dishes were left ajar in a laminar flow chamber at room temperature $\left(21 \pm 2{ }^{\circ} \mathrm{C}\right)$ and relative moisture of $61 \pm 8 \%$. The weight loss of the capsules was monitored using analytical scales, at regular 1-hour intervals in the first $9 \mathrm{~h}, 2$-h intervals from 9 to $15 \mathrm{~h}$, and 3$\mathrm{h}$ intervals from 15 to $21 \mathrm{~h}$; the wet weight was weighed at each of these intervals. The dry weight was measured by heating the Petri dishes with the capsules in a convection oven at $70{ }^{\circ} \mathrm{C}$ for $72 \mathrm{~h}$. The moisture content (MC) was calculated as the difference between wet weight (WW) and dry weight (DW), as follows: 
CG Melo et al.

$$
M C(\%)=\left(\frac{W W-D W}{W W}\right) \times 100 .
$$

The nine replications consisted of a Petri dish with 20 capsules each. Results were analyzed and interpreted using the open-source software R (R Development Core Team 2007).

The osmotic potential of sucrose at different concentrations in precultured capsules was checked in an assay consisting of eight replications (20 capsules replication $^{-1}$ ). The capsules were transferred to Petri dishes after precultivation for two days. Samples were exposed $0.3,0.5$ and $0.75 \mathrm{M}$ sucrose for pre-established time periods to attain 30, 20 and $10 \%$ moisture content. After each period, plates with capsules were weighed to measure the wet weight. The dry weight was measured using the method described above; the same was done with moisture.

\section{Preculture, desiccation, electrolytic leakage and viability tests}

Following polymerization, the encapsulated shoot tips were transferred to a liquid BM medium containing $0.3,0.5$ and $0.75 \mathrm{M}$ sucrose for one and two days, to induce shoot tip tolerance to desiccation. Flasks with capsules (30 capsules flask ${ }^{-1}$ ), with $30 \mathrm{~mL}$ of each of the preculture media, were constantly agitated $(80 \mathrm{rpm})$ in an orbital agitator, at controlled room temperature of $27 \pm 2{ }^{\circ} \mathrm{C}$. Desiccation occurred in Petri dishes, left ajar for this purpose for $0,5.7,7.45$ and $10.1 \mathrm{~h}$, corresponding to the exposure time in the laminar flow chamber required to attain moisture contents of 30,20 and $10 \%$. At the end of these desiccation periods, capsules (10 capsules flask ${ }^{-1}$ ) were transferred to flasks containing BM. These flasks were stored in the dark for seven days and then transferred to an illuminated room.

To determine electrolyte leakage from shoot tips after different drought periods, the shoot tips were removed from their capsules and washed three times in deionized water. The tips were then transferred to test tubes containing deionized water $(10 \mathrm{~mL})$ for $2 \mathrm{~h}$. At this point, the initial electrical conductivity of the solution was measured using a conductivimeter (Tecnal, model Tec-4MP). Total conductivity was attained after the test tubes were autoclaved at $121^{\circ} \mathrm{C}$ and $1.5 \mathrm{~atm}$ for $20 \mathrm{~min}$. The percentage of electrolyte leakage (EL) was measured as follows:

$$
E L(\%)=\frac{I C}{F C} \times 100 .
$$

Where, IC: Initial conductivity and FC: Final conductivity The experiments were based on a $3 \times 2 \times 4$ factorial design (three sucrose concentrations, two preculture periods and four desiccation periods) and control treatments to generate 28 treatments. In the control treatment, capsules were desiccated but not precultured in sucrose solutions. A completely randomized design with three replications was used. Survival rate and electrolytic leakage data were analyzed and interpreted using the software R (R Development Core Team 2007). For the statistical evaluation, analysis of variance was performed and, when necessary, a comparison of means by the Tukey test (5\% significance).

\section{Histological analysis}

Three shoot tips were chosen for histology after the following steps: extraction; $12 \mathrm{~h}$ in BM; one and two days of preculture in $0.3,0.5$ and $0.75 \mathrm{M}$ sucrose solutions; air desiccation in the laminar flow chamber for $0,5.7,7.45$ and $10.1 \mathrm{~h}$; then 0 and 3 days in a recovery medium. Shoot tips were removed from the capsules before processing for microscopy. Samples were fixed in $\mathrm{FAA}_{50}$ for $48 \mathrm{~h}$ at room temperature, desiccated in graded ethanol, and embedded in methacrylate. The blocks were cut in cross and longitudinal sections with a rotary microtome (4 ìm thickness). The sections were stained with toluidine blue (O’ Brien et al. 1964) for metachromasy and with diluted (1:5) Lugol solution (Johansen 1940) for starch detection and analyzed under light microscopy.

\section{RESULTS AND DISCUSSION}

\section{Moisture determination of capsules}

On the potential curve representing the marked reduction in water concentration in capsules following desiccation, the mean initial water content was $96.59 \%$. This mean dropped to $42.65 \%$ after $4 \mathrm{~h}, 17.21 \%$ after $8 \mathrm{~h}$, $4.21 \%$ after $15 \mathrm{~h}$, and $3.59 \%$ after $21 \mathrm{~h}$ of desiccation. The curve showing the variation of moisture content (y axis) in the capsules as a function of drying time ( $\mathrm{x}$ axis) was drawn by straight line segments attached at the midpoints of the moisture corresponding to each time studied (defining the $\mathrm{x}, \mathrm{y}$ coordinates). Since the equation of each line segment can be determined from the endpoint coordinates, the dessication time for each moisture percentage (30, 20 and $10 \%)$ can be calculated by $\mathrm{x}=(\mathrm{y}-\mathrm{a}) / \mathrm{b}$, for $\mathrm{y}=30,20$ or $10 \%$, where $\mathrm{a}$ and $\mathrm{b}$ are the estimates of the straight line 
coefficients ( $a$ is the $y$ intercept and $b$ the slope) for the corresponding line segment on the graph.

In this way, the predetermined 30, 20 and $10 \%$ moisture contents were reached after 5.7, 7.45 and $10.1 \mathrm{~h}$, respectively (Figure 1A). The initial moisture content in encapsulated shoot tips was $96.59 \%$ in the controltreatment, $90.51 \%$ when precultured in a $0.3 \mathrm{M}$ sucrose solution, $86.78 \%$ in a $0.5 \mathrm{M}$ sucrose solution, and $82.60 \%$ in a $0.75 \mathrm{M}$ sucrose solution; this suggested that sucrose had an osmotic potential that decreased moisture in plant tisues precultured in sucrose solution (Figure 1B). Fang et al. (2004) showed that a higher sucrose concentration decreased moisture contents in alginate capsules containing somatic embryos of cocoa by osmotic effects. There were no differences in initial moisture between preculture period ( 1 or 2 days) and moisture loss from capsules when desiccated (data not presented). Suzuki et al. (2006) extracted soluble sugar from axillary buds of gentian precultured with $0.4 \mathrm{M}$ and $0.7 \mathrm{M}$ sucrose for one day at each concentration. These authors observed that preculturing in sucrose-enriched culture medium resulted in a 2.5 -fold sucrose increase in the gentian cells and concluded that preculturing induces storing of sucrose in gentian bud cells. Halmagyi and Deliu (2007) observed that preculture with sucrose increased dry weight of beads compared to preculture without sucrose, and concluded that this indicates that water loss was accompanied by sucrose uptake of the beads. The decreased water loss from precultured capsules exposed to dessication in comparison with the capsules without preculture suggests the same phenomenon in this study as observed by Suzuki et al. (2006) and by Halmagyi and Deliu (2007).

The moisture content in capsules reported in other studies differed, where desiccation was performed in a laminar flow chamber. The moisture content was 23 and $19 \%$ after 5 and $7 \mathrm{~h}$, respectively, for encapsulated shoot tips of bermudagrass (Reed et al. 2005). Moisture reached 21.8 and $16.5 \%$ after 4 and $10 \mathrm{~h}$ in encapsulated shoot tips of citrange (Wang et al. 2002a). Encapsulated shoot tips of grapevine were exposed to 6,8 and $10 \mathrm{~h}$ in the laminar flow chamber, respectively, to reach 17.6, 15.6 and $15.1 \%$ moisture (Wang et al. 2000). As the alginate concentration was the same in all papers reviewed, the variation in moisture content between the different studies was probably due to the temperature and relative humidity of the air in which desiccation was performed, and capsule size and polymerization time. Reed et al. (2005) suggested that temperature and relative humidity are generally not controlled in the desiccation region when material is dried in a laminar flow chamber. Air temperature and relative humidity affect the evaporation rate significantly, which explains differences in results of moisture levels of capsules in different papers after the same desiccation period.

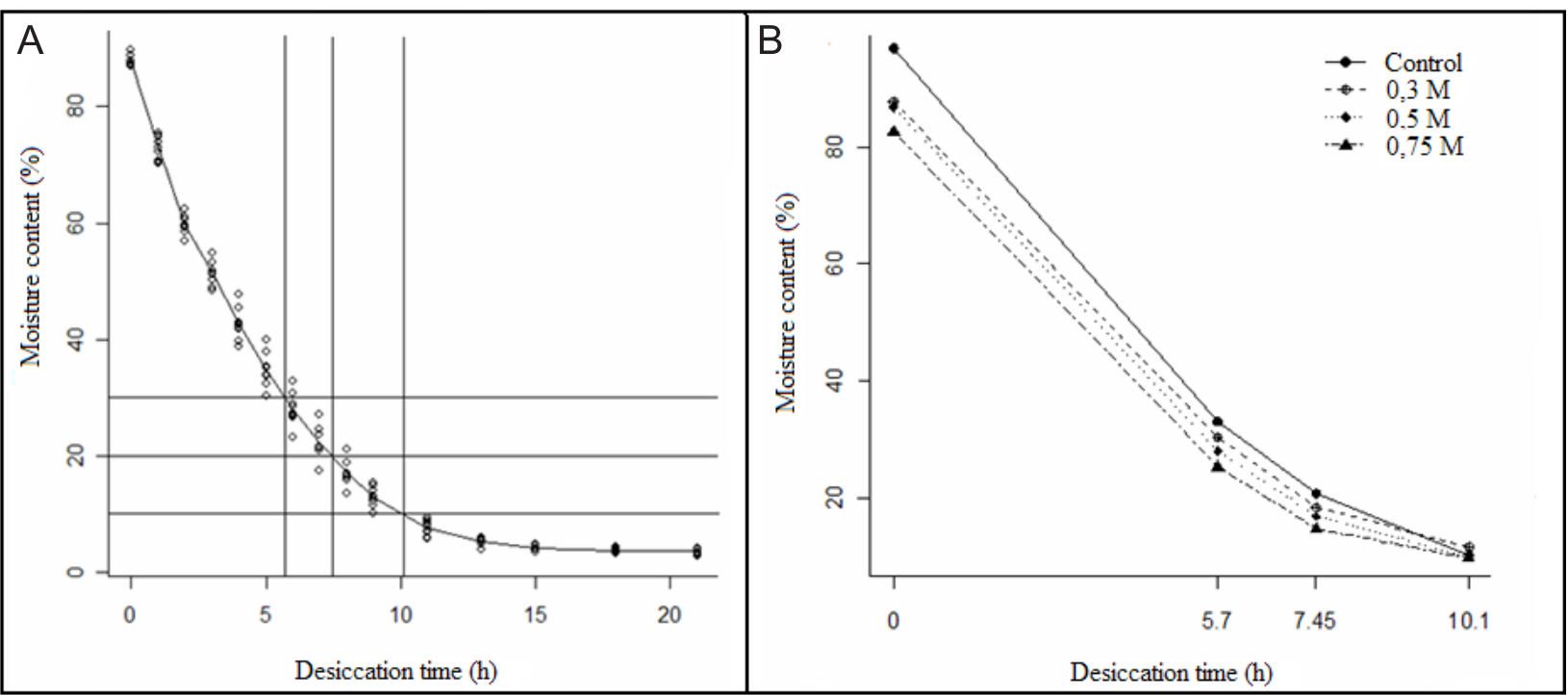

Figure 1. Variation of moisture content in capsules as a function of desiccation period. A) Humidity loss from capsules without preculturing in sucrose solutions, highlighting exposure time to air in a laminar flow chamber to attain 30, 20 and $10 \%$ moisture content. B) Effect of desiccation periods $(0,5.7,7.45$ and $10.1 \mathrm{~h})$ in a laminar flow chamber on the moisture content of encapsulated shoot tips precultured or not in $0.3,0.5$ and $0.75 \mathrm{M}$ of sucrose-enriched media. 
CG Melo et al.

\section{Preculture, desiccation, electrolytic leakage and viability tests}

The control shoot tips were histologically examined soon after extraction (Figures 2A and 2B). The control shoot tips consisted of several primordial leaf pairs and a basal portion. The apical region cells had the typical meristematic features: high nucleus/cytoplasm ratio, dense cytoplasm, small vacuoles, and a large nucleus with one or two apparent nucleoli. Basal region cells were larger and highly vacuolized, with low-density cytoplasm and a low nucleus/cytoplasm ratio. Cells in the tip and basal region did not accumulate starch grains. Starch grains were found to accumulate after $12 \mathrm{~h}$ in BM (Figure 2D). Cells in the tip and basal region preserved the features found in controls except for the presence of starch grains (Figure 2C). This finding showed that cultivating shoot tips in
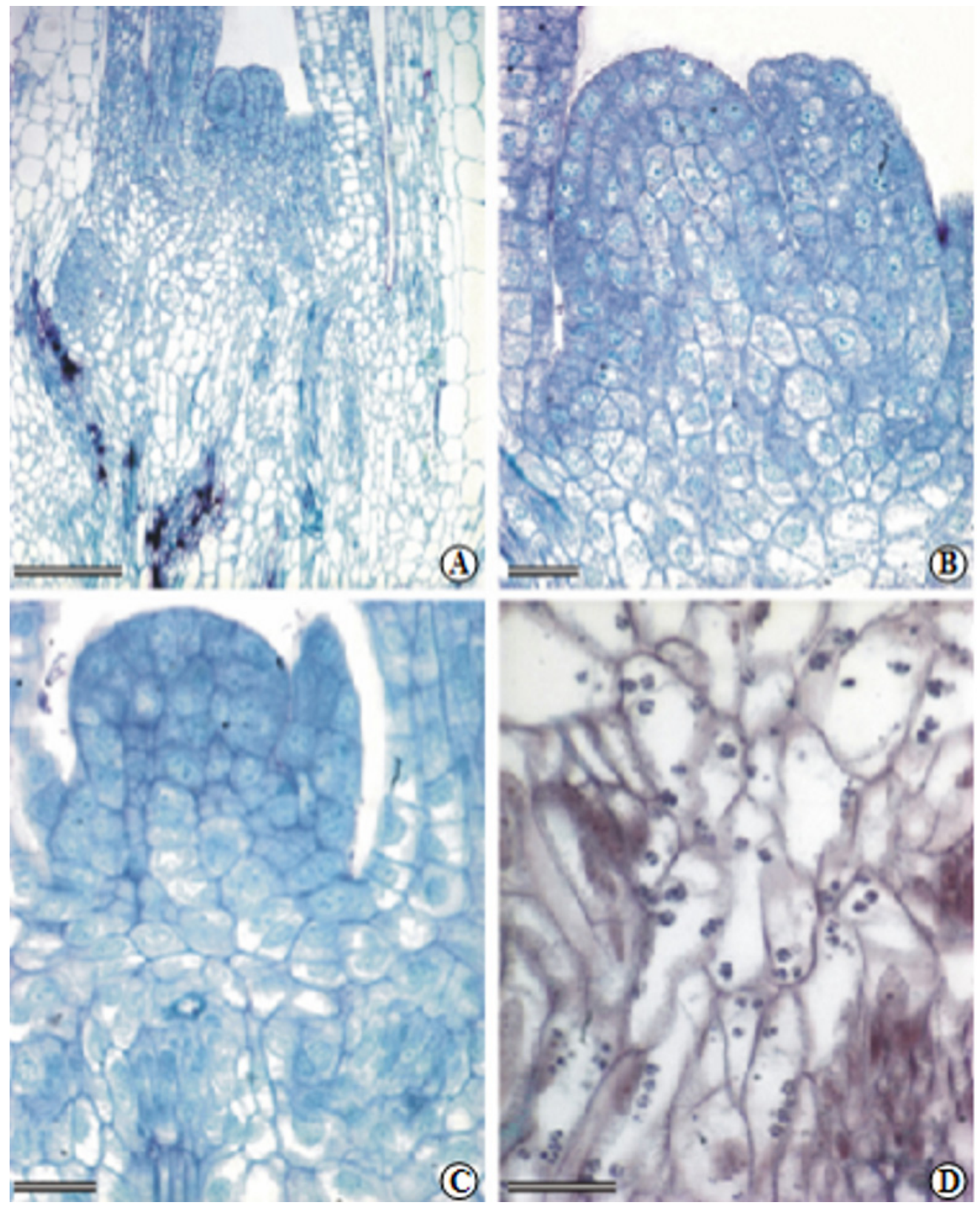

Figure 2. Longitudinal sections of sugar cane shoot tips. A-B) control, shoot tips, immediately after extraction. C-D) shoot tips after $12 \mathrm{~h}$ in BM. Note the presence of starch (dark grains) in D. Bar $=200 \mu \mathrm{m}(\mathrm{A}), 25 \mu \mathrm{m}(\mathrm{B}-\mathrm{C}-\mathrm{D})$. 
$\mathrm{BM}$ for $12 \mathrm{~h}$ reactivates metabolism by accumulating starch grains in cells and helps recover the cells from extraction stress. According to Benson et al. (1989), this is also an important measure to decrease the physiological heterogeneity of tips by synchronizing their metabolism.

The survival rate of control-treatment explants decreased drastically after desiccation. There was, however, no significant difference in the survival rate when desiccated for $10.1 \mathrm{~h}$ (Figure 3A). The survival rate of encapsulated shoot tips, as capsule humidity was reduced, decreased drastically without preculturing. This decrease suggests that the solute effect (altered $\mathrm{pH}$, increased electrolyte concentration, protein denaturing, membrane phase transition, and macromolecular interactions) occurred when water was removed from cells (Lurswijidjarus and Thammasiri 2004). This result shows the importance of preculture for increasing resistance of tissues during desiccation. Without this step the use of cryopreservation for the long-term storage of sugarcane's genetic resources is infeasible. The electrolytic leakage rate increased with longer desiccation periods in the control treatment (Figure 3B). Cell leakage indicates that the cell membrane is physically damaged, and is one of the main causes of cell death (Verleysen et al. 2004). Working with somatic embryos of Picea glauca, Spathoglottis plicata orchidaceae protocorms and seeds of Euterpe edulis, respectively, Percy et al. (2001), Wang et al. (2002b) and Panza et al. (2007) found that electrolytic leakage from explants permeability and decreases cell tolerance to this type of stress.

The high survival rate of shoot tips exposed to desiccation after preculturing in $0.3 \mathrm{M}$ sucrose and the low electrolytic leakage rate (Figure 3B) suggest that the $0.3 \mathrm{M}$ sucrose concentration effectively protected the double layer and proteins during desiccation. Preculture in a $0.5 \mathrm{M}$ sucrose solution resulted in higher explant survival rates after 5.7 and $7.45 \mathrm{~h}$ of desiccation (Figure $3 \mathrm{~A})$. The concentration of $0.5 \mathrm{M}$ resulted in an atypical behavior, with no apparent biological and/or physiological explanation. A higher survival rate would have been expected when the explants were not exposed to dessication. The survival rate of explants at time zero was higher when precultured in $0.75 \mathrm{M}$ sucrose solution; exposure to desiccation for 5.7, 7.45 and $10.1 \mathrm{~h}$ abruptly reduced the survival rate, although there was no significant difference among these three desiccation periods (Figure $3 \mathrm{~A})$. There was a progressive increase in the electrolytic leakage rate of non-desiccated shoot tips at 0.5 and 0.75 $\mathrm{M}$ sucrose concentrations in the preculture medium (Figure 3B).

There was a significant increase in the survival rate of shoot tips when precultured for two days in a $0.5 \mathrm{M}$ sucrose culture medium (Figure 4A). There was no significant difference in preculture periods at 0.3 and 0.75 M sucrose concentrations (Figure 4A). Wang et al. (2005)

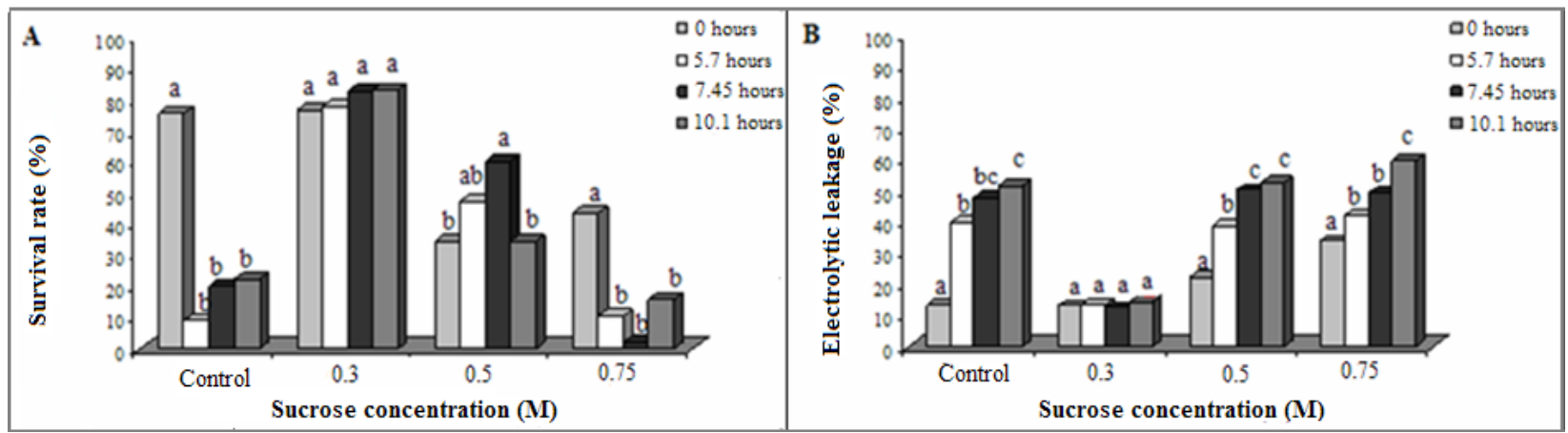

Figure 3. Effect of preculture in sucrose-enriched BM on survival rate of shoot tips and electrolytic leakage. A). Tissue tolerance to desiccation after $0,5.7,7.45$ and $10.1 \mathrm{~h}$, as indicated by mean survival rate of shoot tips. B) Effect of different sucrose concentrations on tolerance of shoot tips when exposed or not to desiccation, as indicated by the mean electrolytic leakage rate. Statistically, bars with the same letters were not different at $5 \%$ probability (Tukey test) within each sucrose concentration.

increased during desiccation, especially at lower humidity levels. Percy et al. (2001) and Panza et al. (2007) associated this increase with injury due to cell membrane desiccation. According to Liang and Sun (2000), these findings confirm the hypothesis that desiccation increases membrane noted that the survival rate of encapsulated raspberry shoot tips was affected by the preculture period. According to these authors, when preculturing lasted 1-3 days, the shoot tip survival rate was relatively constant, but decreased after longer periods. The survival rate was statistically 


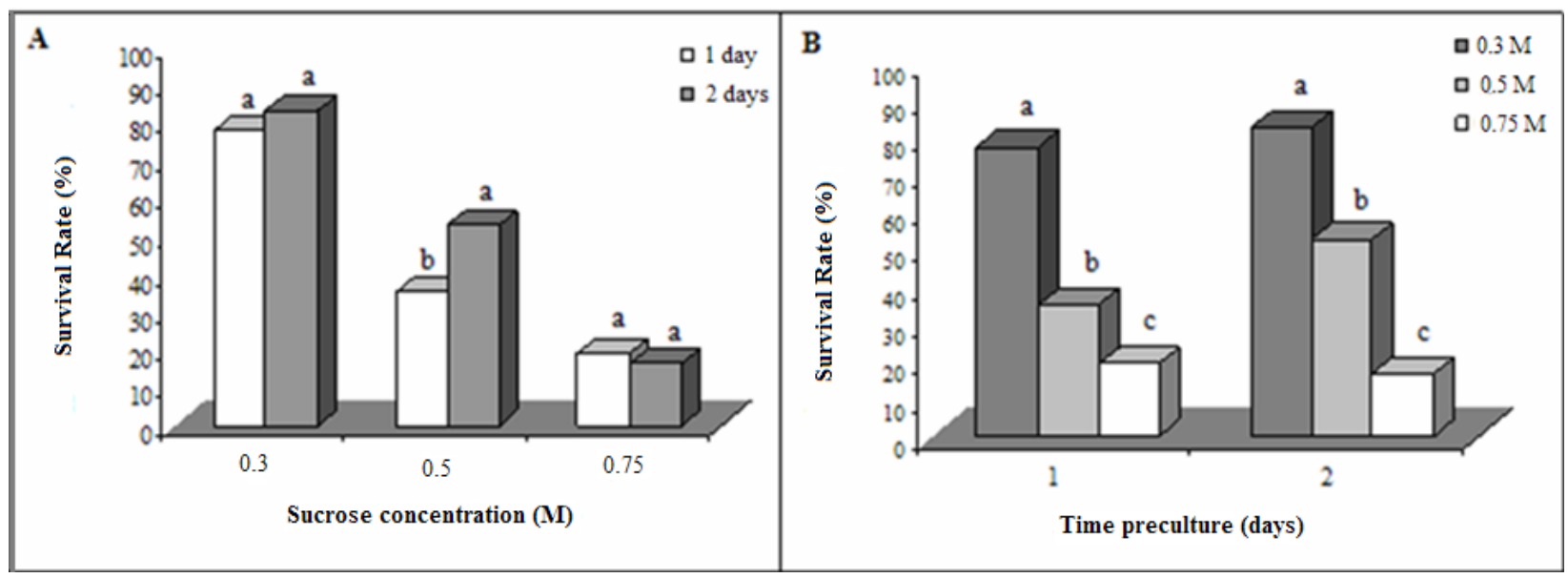

Figure 4. Effect of sucrose concentrations and preculture periods on the mean survival rate of explants. A) Effect of sucrose concentrations associated with preculture periods on the mean survival rate of explants. Statistically, bars with the same letters were not different at $5 \%$ probability (Tukey test) within each sucrose concentration. B) Effect of preculture period in sucrose solutions on the mean explant survival rate. For similar preculture periods, bars with the same letters were statistically not different at $5 \%$ probability (Tukey test).

different, regardless of the preculture period at the three sucrose concentrations studied (Figure 4B). Highest explant survival rates were achieved with the $0.3 \mathrm{M}$ sucrose concentration, followed by $0.5 \mathrm{M}$ concentration; performance was worst at $0.75 \mathrm{M}$ (Figure 4B). There was no significant difference among desiccation periods in the experiments when explants were precultured in a $0.3 \mathrm{M}$ sucrose solution (Figure 3A). The protective properties of sugars during desiccation in plant cells are known (Halperin and Koster 2006). Sugars stabilize membranes and proteins during dehydration, replacing the water if cell drying occurs slowly (Hoekstra et al. 2001b). In the latter situation, sugars are believed to replace water and form hydrogen bonds with macromolecules, protecting their structure and preventing phase transition in membranes (Hoekstra et al. 2001b).

The electrolytic leakage rate increased after longer desiccation periods in the control treatment and in the tissues precultured in 0.5 and $0.75 \mathrm{M}$ sucrose solutions. The electrolytic leakage rate in shoot tips was high when precultured in culture media containing 0.5 and $0.75 \mathrm{M}$ sucrose, indicating that these two sucrose concentrations are harmful and increase the permeability of cell membranes. The concentration of $0.75 \mathrm{M}$ is, on the one hand, more adequate for a number of species such as apple (Paul et al. 2000), grape (Wang et al. 2000) and citrange (Wang et al. 2002a), for ensuring high survival rates in cryopreserved shoot tips, but is, on the other hand, harmful for banana (Panis et al. 1996) and decreased the viability of dehydrated cells of embryogenic cell suspensions of grapevine (Wang et al. 2004). According to Halmagyi et al. (2010), high sucrose concentrations resulted in excessive cell dehydration, causing explant death. Panis et al. (1996) associated a zero survival rate in banana buds precultured in a $0.75 \mathrm{M}$ sucrose-enriched medium with an osmotic shock, due to this high sucrose concentration in explants. Sugar cane shoot tips in our study were also sensitive to the $0.75 \mathrm{M}$ concentration.

Irrespective of the sucrose concentration, the cell structure is altered by desiccation; the cytoplasm may retract and move away from the cell wall (Figure 5A). After three days in a regenerating medium, shoot tip cells were able to recover their initial properties (Figure 5B). The histologic analyses of shoot tips performed immediately after desiccation and after three days in a regenerating medium suggested that desiccation causes cell damage and that three days in regeneration medium rehydrated the cells. 

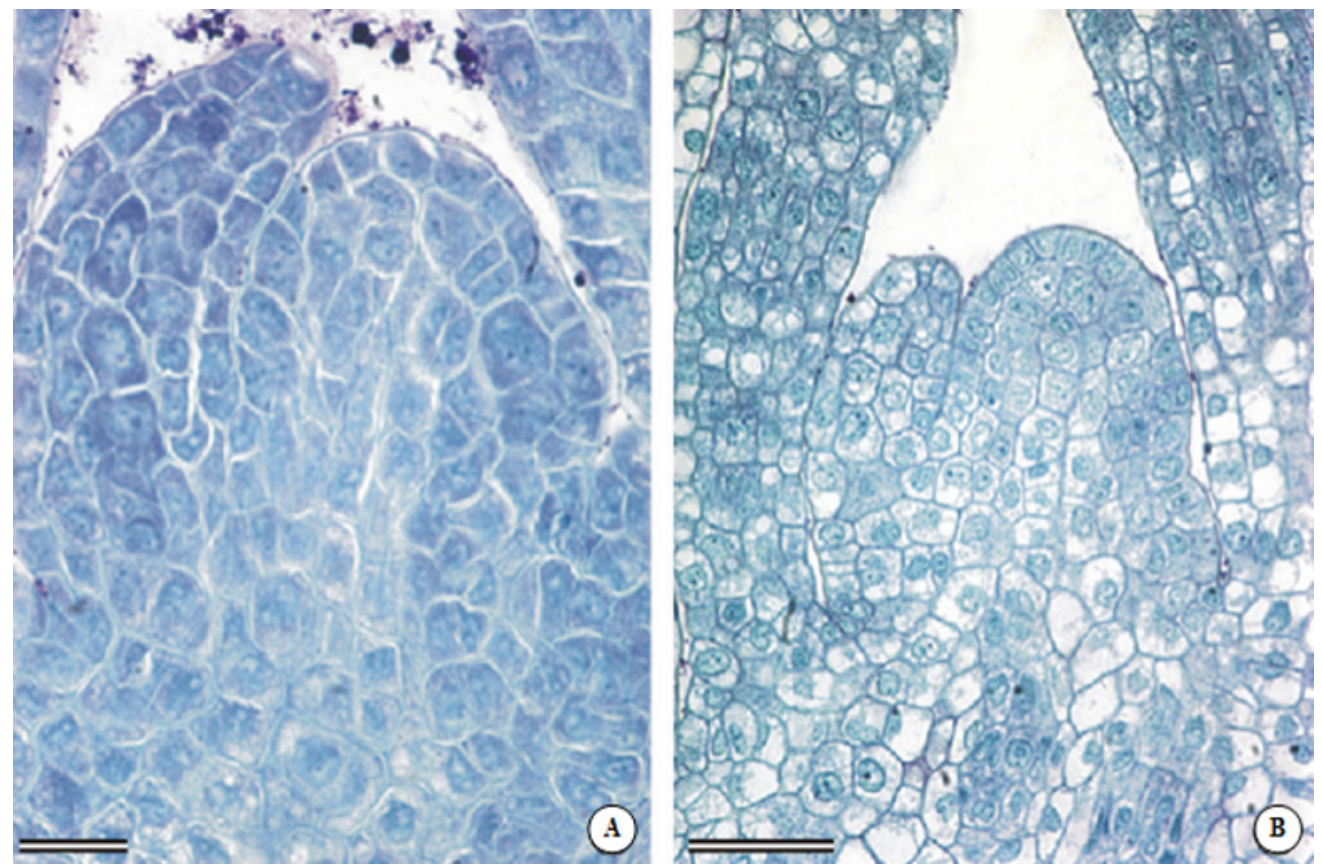

Figure 5. Longitudinal sections of sugar cane shoot tips. A) Preculture in $0.3 \mathrm{M}$ sucrose solution for one day and desiccation for $10.1 \mathrm{~h}$. B) Preculture for one day in $0.3 \mathrm{M}$ sucrose solution and desiccation for $10.1 \mathrm{~h}$ after three days in BM. Note the retracted cytoplasm in A. $\operatorname{Bar}=25 \mu \mathrm{m}(\mathrm{A}), 50 \mu \mathrm{m}(\mathrm{B})$.

\title{
ACKNOWLEDGEMENTS
}

The authors are indebted to the research foundation of the state of Minas Gerais FAPEMIG (Fundação de Amparo à Pesquisa do Estado de Minas Gerais) for research scholarships and financial support.

\section{Pré-cultivo em meio de cultura suplementado com sacarose para a aquisição de tolerância dos tecidos de cana-de-açúcar à secagem}

\begin{abstract}
RESUMO - A criopreservação é uma técnica promissora para a conservação em longo prazo dos recursos genéticos da cana-deaçúcar que poderão ser utilizados nos programas de melhoramento. O pré-cultivo é uma etapa chave para se obter sucesso nesta técnica. O objetivo deste estudo foi avaliar o efeito de concentrações de sacarose e tempo de pré-cultivo na resistência dos tecidos de cana-de-açúcar quando desidratados para 30, 20 e $10 \%$ de umidade. Ápices caulinares de cana-de-açúcar foram encapsulados em alginato de sódio e pré-cultivados em meio de cultura líquido contendo 0,3, 0,5 e 0,75 M de sacarose. O pré-cultivo em 0,3 M de sacarose foi ideal para induzir a tolerância dos tecidos à secagem. Esta concentração resultou em baixa porcentagem de vazamento eletrolítico. Os ápices foram sensíveis à concentração de 0,75 M de sacarose resultando em baixo índice de sobrevivência dos explantes quando submetidos ou não à secagem. O pré-cultivo em 0,5 M de sacarose resultou em maior índice de sobrevivência dos ápices quando expostos à secagem por 5.7 e 7.45 horas. O pré-cultivo ou não em 0,5 e 0,75 M de sacarose resultou em alta porcentagem de vazamento eletrolítico dos ápices expostos à secagem.
\end{abstract}

Palavras-chave: vazamento eletrolítico; ápices caulinares; cultura de tecidos. 


\section{REFERENCES}

Benson EE, Harding K and Smith H (1989) Variation in recovery of cryopreserved shoot-tips of Solanum tuberosum exposed to different pre- and post-freeze light regimes. Cryo-Letters 10: $323-344$.

Bogaart GVD, Hermans N, Krasnikov V, Vries AH de and Poolman B (2007) On the decrease in lateral mobility of phospholipids by sugars. Biophysical Journal 92: 1598-1605.

Cacela C and Hincha DK (2006) Low amounts of sucrose are sufficient to depress the phase transition temperature of dry phosphatidylcholine, but not for lypoprotection of liposomes. Biophysical Journal 90: 2831-2842.

Crowe JH, Crowe LM, Oliver AE, Tsvetkova N, Wolkers W and Tablin F (2001) The trehalose myth revisited: introduction to a symposium on stabilization of cells in the dry state. Cryobiology 43: 89-105.

Fabre J and Dereuddre J (1990) Encapsulation-dehydration: a new approach to cryopreservation of Solanum shoot-tips. CryoLetters 11: 413-426.

Fang JY, Wetten A and Hadley P (2004) Cryopreservation of cocoa (Theobroma cacao L.) somatic embryos for long-term germplasm storage. Plant Science 166: 669-675.

Halmagyi A and Deliu C (2007) Cryopreservation of carnation (Dianthus caryophyllus L.) shoot tips by encapsulationvitrification. Scientia Horticulturae 113: 300-306.

Halmagyi A, Vãlimãreanu S, Coste A, Deliu C and Isac V (2010) Cryopreservation of Malus shoot tips and subsequent plant regeneration. Romanian Biotechnological Letters 15: 7985 .

Halperin SJ and Koster KL (2006) Sugar effects on membrane damage during desiccation of pea embryo protoplasts. Journal of Experimental Botany 57: 2303-2311.

Hoekstra F, Golovina EA and Buitink J (2001a) Mechanisms of plant desiccation tolerance. Trends in Plant Science 6: 431438 .

Hoekstra F, Golovina EA, Tetteroo FAA and Wolkers WF (2001b) Induction of desiccation tolerance in plant somatic embryos: how exclusive is the protective role of sugars? Cryobiology 43: $140-150$.

Johansen DA (1940) Plant microtechnique. McGraw-Hill, New York, 523p.

Koster KL, Lei YP, Anderson M, Martin S and Bryant G (2000) Effects of vitrified sugars on phosphatidylcholine fluid-to-gel phase transitions. Biophysical Journal 78: 1932-1948.

Lenné T, Bryant G, Holcomb R and Koster KL (2007) How much solute is needed to inhibit the fluid to gel membrane phase transition at low hydration? Biochimica et Biophysica Acta 1768: 1019-1022.
Liang Y and Sun WQ (2000) Desiccation tolerance of recalcitrant Theobroma cacao embryonic axes: the optimal drying rate and its physiological basis. Journal of Experimental Botany 352: 1911-1919.

Lurswijidjarus W and Thammasiri K (2004) Cryopreservation of shoot tips of Dendrobium walter oumae by encapsulation/ dehydration. Science Asia 30: 293-299.

Machado Neto NB and Durães MAB (2006) Physiological and biochemical response of common bean varieties treated with salicylic acid under water stress. Crop Breeding and Applied Biotechnology 6: 269-277.

Machado Neto NB, Custódio CC, Gatti AB, Priolli MR and Cardoso VJM (2004) Proline: use as an indicator of temperature stress in bean seeds. Crop Breeding and Applied Biotechnology 4: $330-337$.

Murashige T and Skoog F (1962) A revised medium for rapid growth and bio-assay with tobacco tissue cultures. Physiologia Plantarum 15: 473-497.

O'Brien TP, Feder N and McCully ME (1964) Polychromatic staining of plant cell walls by toluidine blue O. Protoplasma 59: $367-373$.

Oliver AE, Hincha DK and Crowe JH (2002) Looking beyond sugars: the role of amphiphilic solutes in preventing adventitious reactions in anhydrobiotes at low water contents. Comparative Biochemistry and Physiology Part A: Molecular \& Integrative Physiology 131: 515-525.

Panis B, Totte T, Van Nimmen K, Wither LA and Swennen R (1996) Cryopreservation of banana (Musa spp.) meristem cultures after preculture on sucrose. Plant Science 121: 95106.

Panza V, Láinez V, Maldonado S and Maroder HL (2007) Effects of desiccation on Euterpe edulis Martius seeds. Biocell 31: 383-390.

Paul H, Daigny G and Sangwan-Norreel BS (2000) Cryopreservation of apple (Malus $\times$ domestica Borkh.) shoot tips following encapsulation-dehydration or encapsulation-vitrification. Plant Cell Reports 19: 768-774.

Percy REL, Livingston NJ, Moran JA and Von Aderkas P (2001) Desiccation, cryopreservation and water relations parameters of white spruce (Picea glauca) and interior spruce (Picea glauca $\times$ engelmannii complex) somatic embryos. Tree Physiology 21: $1303-1310$.

Popov AS, Popova EV, Nikishina TV and Vysotskaya ON (2006) Cryobank of plant genetic resources in Russian Academy of Sciences. International Journal of Refrigeration 29: 403 410 .

R Development Core Team (2007) A language and environment for statistical computing. R Foundation for Statistical Computing. Available at <http://www.R-project.org > Accessed on Jul. 20, 2007. 
Reed BM, Schumacher L, Wang N, D'Achino J and Barker RE (2005) Cryopreservation of bermudagrass germplasm by encapsulation-dehydration. Crop Science 46: 6-11.

Sakai A (2004) Plant cryopreservation. In Fuller B, Lane N and Benson EE (eds.) Life in the frozen state. CRC Press, London, p. 329-346.

Suzuki M, Ishikawa M, Okuda H, Noda K, Kishimoto T, Nakamura T, Ogiwara I, Shimura I, and Akihama T (2006) Physiological changes in gentian axillary buds during two-step preculturing with sucrose that conferred high levels of tolerance to desiccation and cryopreservation. Annals of Botany 97: 1073-1081.

Verleysen H, Van Bockstaele E and Debergh P (2005) An encapsulation-dehydration protocol for cryopreservation of the azalea cultivar 'Nordlicht' (Rhododendron simsii Planch.). Scientia Horticulturae 106: 402-414.

Verleysen H, Samyn G, Van Bockstaele E and Debergh P (2004) Evaluation of analytical techniques to predict viability after Cryopreservation. Plant Cell, Tissue and Organ Culture 77: 11-21.

Wang Q, Laamanen J, Uosukainen M and Valkonen JPT (2005) Cryopreservation of in vitro-grown shoot tips of raspberry (Rubus idaeus L.) by encapsulation-vitrification and encapsulation-dehydration. Plant Cell Reports 24: 280-288.
Wang Q, Mawassi M, Sahar N, Li P, Violeta CT, Gafny R, Sela I, Tanne E and Perl A (2004) Cryopreservation of grapevine (Vitis spp.) embryogenic cell suspensions by encapsulationvitrification. Plant Cell, Tissue and Organ Culture 77: 267-275.

Wang Q, Batuman Ö, Li P, Bar-Joseph M and Gafny R (2002a) A simple and efficient cryopreservation of in vitro-grown shoot tips of 'Troyer' citrange [Poncirus trifoliata Raf. $\times$ Citrus sinensis (L.) Osbeck.] by encapsulation-vitrification. Plant Cell Reports 20: 901-906.

Wang XJ, Loh CS, Yeoh HH, Sun WQ (2002b) Drying rate and dehydrin synthesis associated with abscisic acid-induced dehydration tolerance in Spathoglottis plicata orchidaceae protocorms. Journal of Experimental Botany 53: 551-558.

Wang Q, Tanne E, Arav A and Gafny R (2000) Cryopreservation of in vitro-grown shoot tips of grapevine by encapsulationdehydration. Plant Cell, Tissue and Organ Culture 63: 41-46.

Wither LA and Engelmann F (1998) In vitro conservation of plant genetic resources. In: Altman A (ed.) Agricultural Biotechnology. Editora Marcel Dekker, New York, p. 57-88.

Wolfe J and Bryant G (1999) Freezing, Drying, and/or Vitrification of Membrane-Solute-Water Systems. Cryobiology 39: 103129. 